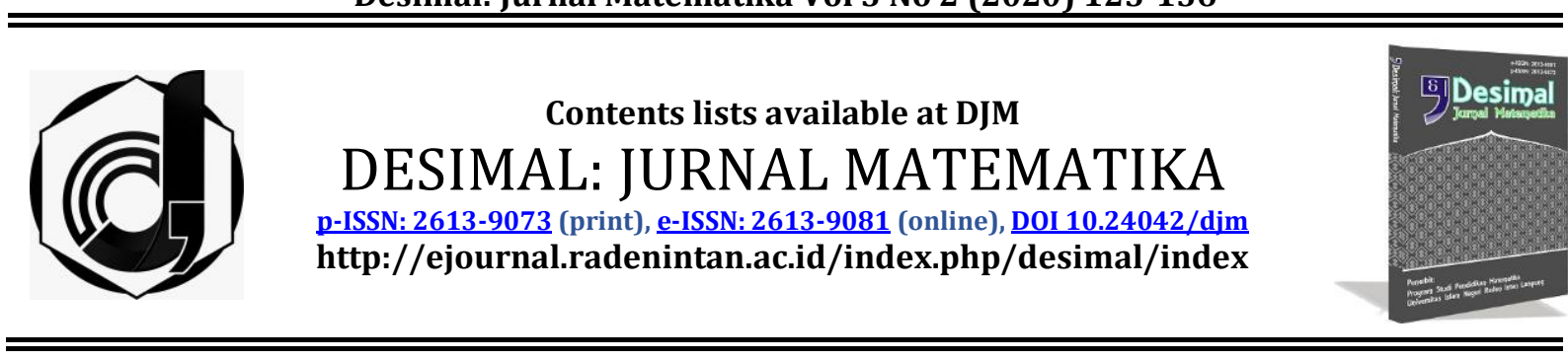

\title{
Students' Errors in Mathematical Problem-Solving Ability on the Triangular and Quadrilateral Materials at Junior High Schools (SMP) Jakarta
}

\author{
Rosida Yahya Asriyani, Isnaini Handayani*, Windia Hadi \\ Universitas Muhammadiyah Prof. DR. HAMKA, Indonesia
}

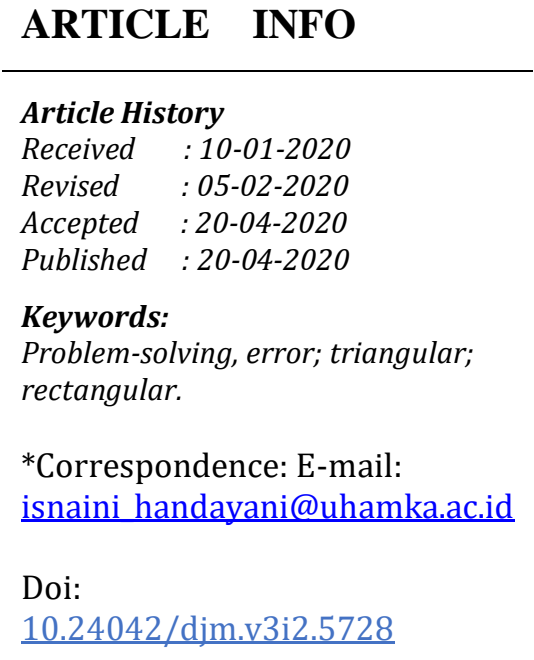

\section{ARTICLE INFO}

\section{Article History}

Problem-solving, error; triangular;

\begin{abstract}
This research was aimed to analyze student's errors on triangular and quadrilateral material in terms of problemsolving ability. This research was motivated by the low problem-solving ability and errors often made by students during the mathematics learning. The research approach was descriptive-qualitative that was done by analyzing the students' difficulty in solving description problems. The techniques of data collection were observation, learning outcomes tests, and interviews. The data were analyzed qualitatively based on Newman Error Analysis. Based on the results of the research, it was found that students' reading errors were in the high, medium, and low categories. Students' comprehension errors were in the medium and low categories, students' transformation errors were in the high, medium, and low categories, students' process skills errors were in the high, low, and medium categories and students writing errors (encoding error) were in the high, medium, and low categories.
\end{abstract}

\section{INTRODUCTION}

One of the goals of learning mathematics according to (Badan Standar Nasional Pendidikan, 2006) is solving problems that include the ability to understand problems, design mathematical models, solve the models, and interpret the solutions obtained. Because the mathematical problemsolving ability is one of the goals of learning mathematics, the ability to solve problems is important to master. This is supported by (Amam, 2019; Fauziah, Maya, \& Fitrianna, 2018; Ulvah \& Afriansyah, 2016) who state that the problem-solving ability is the heart of mathematics. Besides, the problemsolving ability is not only applied in mathematics but in daily life and other fields of study. 
However, in reality, students' mathematical problem-solving ability is still relatively low. The result of research conducted by (Ahmad, 2017) reveals that, based on observations and interviews, the problem-solving ability of students of SMPN 2 is unsatisfactory. Research conducted by (Aisyah, Khasanah, Yuliani, \& Rohaeti, 2018) reveals that the junior high school students' problem-solving ability at West Bandung is classified as low, especially in terms of triangular and quadrilateral materials. One contributing factor is that students have difficulty in understanding non-routine questions, especially in triangular and quadrilateral materials. This is confirmed by the results of the study by (Sholihah \& Afriansyah, 2017) which concluded that students had difficulty in analyzing the nature of the two-dimensional rectangular figures. Research conducted by (Yuwono, 2016) ) reveals that there are three types of difficulties experienced by students in triangular material, namely difficulty in understanding concepts, identifying and mentioning the properties of various triangles, and determining formula to be used.

In line with this, the results of research conducted by (Hadiyanti, 2016) state that there are several types of errors made by students in solving problems of two-dimensional rectangular figures, namely errors in translating problems including errors in determining the length of the sides of a square, concepts errors in determining the formula for circumference and length of square and rhombus, and calculation errors. Based on research conducted by (Aisyah, Nurani, et al., 2018) in West Bandung, (Hadiyanti, 2016) in Kotaraja, and (Fitriatien, 2019) in Cimahi, the students' problem-solving ability on triangular and quadrilateral figures were still low. Therefore, it is necessary to do an error analysis through the Newman procedure.
The Newman Procedure is a method for analyzing errors in the form of description problems. Newman (Fitriatien, 2019) suggests five stages of activities that can find the errors in mathematical problem-solving, namely reading, comprehending, transforming, process skill, and writing the final answer or encoding. The five stages of the Newman procedure are briefly explained by(Yusnia \& Fitriyani, 2016) namely: (a) reading errors occur when students cannot read questions and notations correctly, (b) understanding errors occur because students do not understand the problems, (c) transformation errors occur. After all, students do not know the formula to be used, (d) process skill errors, and (e) decoding errors occur when the students write incorrect conclusions as final answers to problems.

Several previous studies have been done to investigate the types of students' errors in solving mathematical problems (Aisyah, Khasanah, et al., 2018; Hadiyanti, 2016; Sari \& Aripin, 2018; Yusnia \& Fitriyani, 2016). However, there has been no research that describes the types of errors according to the Newman procedure that refers to the level of problem-solving ability. The difference between this study and the previous ones is that this study describes the types of errors according to Newman's procedure that refers to the level of mathematical problem-solving ability, especially on triangular and quadrilateral material so that the cause of the error is known.

\section{METHOD}

The method used in this research was a descriptive qualitative research method to describe students' errors based on the types of Newman's errors. The study was conducted in the second semester of the 2019/2020 academic year at SMP N 51 Jakarta, located at Cendani Raya st., RT 2 / RW.8, Pondok Bambu, Duren Sawit District, East Jakarta. The 
research subjects were 5 seventh-grade students representing each category of mathematical problem-solving ability, namely high, medium, and low. Data analysis used was data reduction, data presentation, and concluding. Data collection techniques used in this study included:

1. Observation. The observation was to determine which class had completed the triangular and quadrilateral materials.

2. Test. The test instrument used in this was a description test consisted of five items.

3. Interview. The interviews were conducted to 5 selected students based on the mathematical problemsolving ability test scores.

\section{RESULTS AND DISCUSSION}

Data Description and Research Subjects The data in this study were obtained from the test results of students' mathematical problem-solving ability by selecting 5 research subjects. The subjects were 5 fourth-grade students of class VII4. To be specific, 1 student was categorized to have a high mathematical problem-solving ability, 2 students with moderate mathematical problem-solving ability, and 2 students with low mathematical problem-solving ability. Research by (Rianti, 2018) states that student who obtains an average score of $24.44 \%$ is included in the poor category and possesses the low ability and student who obtains an average score of $61.11 \%$ is included in the moderate category and possesses a high problem-solving ability. The maximum score for each question was 6 with the maximum score of all 30 points. The categorization of mathematical problem-solving ability can be seen in Table 1.
Table 1. Categorization of Problemsolving Ability

\begin{tabular}{cl}
\hline Student' Score & Qualification \\
$5-12$ & Low \\
$13-21$ & Moderate \\
$21-30$ & High \\
\hline
\end{tabular}

The research subjects were selected based on the results of tests of mathematical solving ability. It was done through a purposive sampling technique by considering the appropriateness of characteristics and errors. The details of the selected subjects are presented in Table 2.

Table 2. List of Research Subjects

\begin{tabular}{ccc}
\hline $\begin{array}{c}\text { Research } \\
\text { subjects }\end{array}$ & Groups & $\begin{array}{c}\text { Level } \\
\text { Ability }\end{array}$ \\
S25 & Low & High \\
S17 & Moderate & Moderate \\
S31 & Moderate & Moderate \\
S2 & High & Low \\
S23 & High & Low \\
\hline
\end{tabular}

Error Analysis

The error analysis model used was Newman's analysis of reading errors, comprehension errors, transformation errors, process skill errors, and writing errors (encoding error). Based on the results of the tests and interviews, the types of errors made by the five subjects are described as follows:

\section{Reading Error}

The subjects are said to make a reading error if they are unable to read, recognize, and interpret the meaning of each word, term, or symbols of the problem. The explanation of the reading errors made by each category of problemsolving ability is as follows:

a. Subjects with High Mathematical Problem-solving ability

In subjects with high mathematical problem-solving ability, the reading errors found were in items 2 and 5 . The following is an excerpt from an interview with one of the subjects regarding item 2 .

R: Now continue to number 2, please read it one more time. 
S25: An ABC triangle is known to have a large angle of $\mathrm{BAC}=55$ degrees. The angle of $A B C$ is greater than 20 degrees from the $B A C$ angle. Point $D$ is located on the $A B$ side and point $E$ is on the $\mathrm{BC}$ side, so $\mathrm{DB}=\mathrm{DE}$. What is the magnitude of the BDE angle? Which side is the longest of the $A B C$ triangle?

The subject was able to read, but there was a slight error in the reading process. The correct one should be "the ACB angle is greater than 20 degrees from the BAC angle".

\section{b. Subjects with Medium Mathematical Problem-solving Ability}

The subjects in this mathematical problem-solving ability category did reading errors when reading items 3 and 4. The following is an excerpt from an interview with one of the subjects regarding item 3.

R: Please read item 3 one more time.

S31: To help you answer, draw a rectangle. There is an ABCD trapezoid where one of the parallel sides is three times the length of the other parallels. ABCD trapezoid height is the average of the lengths of the two parallel sides. If the area of the trapezoid is 576 square centimeters. Calculate the height and length of the parallel sides of the ABCD trapezoid.

Subjects were able to read the questions although there was a slight error when reading the nominal of 576 . S31 mentioned "five hundred seven six" where correct one should be "five hundred and seventy-six"

\section{c. Subjects with Low Mathematical Problem-solving Ability \\ The subjects with low} mathematical problem-solving ability did an error when reading item 3 . The following is an excerpt from an interview with one of the subjects regarding item 3 . R: Try read question number 3 .
S23: There is an ABCD trapezoid where one side is parallel with three times the length of other parallel sides. $\mathrm{ABCD}$ trapezoid height is the average of the lengths of the two parallel sides. If the area of the trapezoid is $576 \mathrm{~cm}$ squared, calculate the height and length of the sides parallel to the ABCD trapezoid.

S23 experienced reading errors when reading units of a wide area. The unit of area read by S23 was "centimeter squared" where it should be "square centimeter".

It can be concluded that all subjects experienced reading errors even though the indicators were different. This was supported by the results of the study by (Oktaviana, 2018) which that reveals there are $24 \%$ of students who experience errors in reading questions because they do not know the keywords/meaning of the questions. However, the results of this study by (Yusnia \& Fitriyani, 2016) states that the error at the reading stage (reading error) is $0.00 \%$ which means that all students can read the questions properly and correctly.

\section{Comprehension Error}

The subject is said to have experienced a comprehension error when he/she is unable to understand and write what is known and asked about the problem. The explanation of the location of the misunderstanding is done by each category of problem-solving ability as follows:

a. Subjects with High Mathematical Problem-solving ability

The subjects with high mathematical problem-solving ability did not experience comprehension errors.
b. Subjects with Moderate Mathematical Problem-solving ability
The subjects with moderate mathematical problem-solving ability could not comprehend the problem 
completely and did not write down the problem completely. The following is an example of an answer by subject with moderate problem-solving ability in item 1.

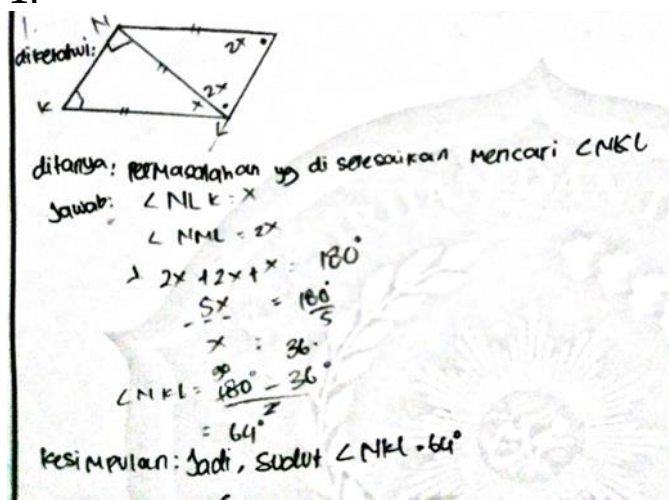

Figure 1. Test Answers of Students' with Moderate Mathematical Problem-solving Ability

It can be seen that the subject understood the information and problems in item number 1 . To clarify the results of the analysis, an interview was conducted. The following are the interview excerpts: R: Okay, for question number 1 , do you understand the problem that needs to be solved?

S31: Hmm ... that one ... NLK angle eh NKL angle.

Based on the results of the analysis of the answers and interviews, it can be concluded that S31 experienced a comprehension error. The subject was able to write down information and problems of item number 5 but can not explain in full when interviewed by researchers.

c. Subjects with Low Mathematical Problem-solving ability

The subjects with low mathematical problem-solving ability cannot understand the problem completely and did not write down the problem and completed the problem information. The following is a sample answer for item 3 :

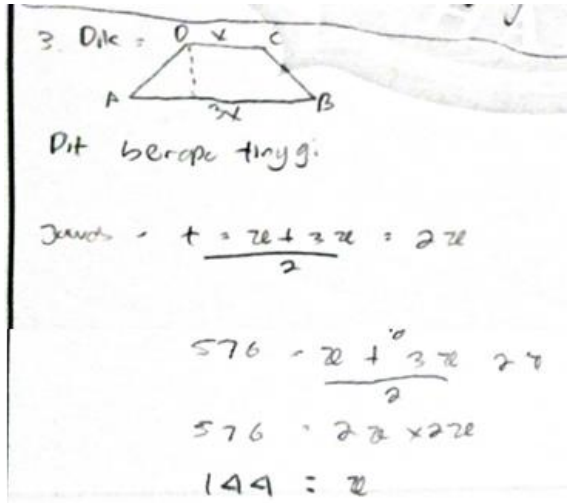

Figure 2: Test Answer of Students with Low Mathematical Problem-solving Ability

The subjects only wrote 1 problem on the answer sheet while there were supposed to be 3 problems on the answer sheet. Therefore, to find out whether the subject understood the problem of item 3 , an interview was conducted. The following is an excerpt of an interview with the subject:

R: On problem number 3, what problems must be solved?

S2: Hm ... the one that was asked was for the height in this picture

Based on the results of the analysis of the answers and interviews with the subject, it can be concluded that the subject experienced a misunderstanding (comprehension error) because the subject did not understand the problem in full.

It can be concluded that there were more indicators of errors in the students with low mathematical problem-solving ability compared to the students with moderate problem-solving ability.

\section{Transformation Error}

The subject is said to make a transformation error when the subject knows what is needed from the question but fails to identify mathematical operations and make or change them into sentences or mathematical models. The errors made by each category of problemsolving ability is as follows: 
a. Subjects with High Mathematical Problem-solving ability

The subject with high mathematical problem-solving ability did a transformation error when converting information into mathematical notation. The following is a sample answer by the subject with high problem-solving ability regarding item 3 :

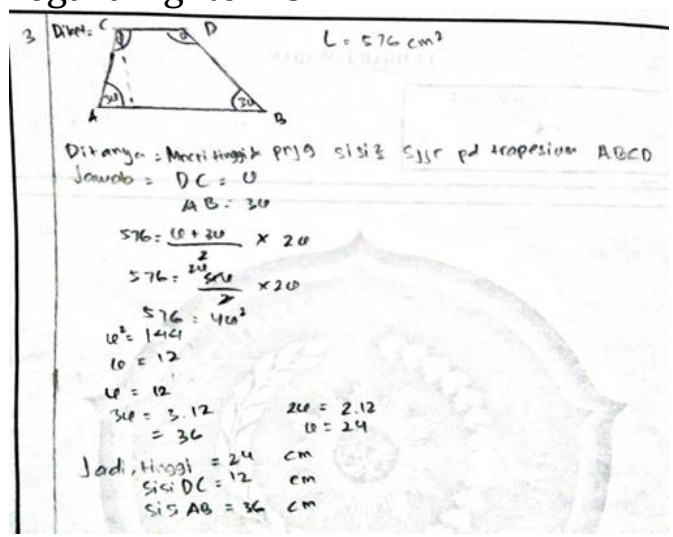

Figure 3. An Answer by a Student with High Mathematical Problem-solving Ability

Based on Figure 3, it can be seen that the subject 25 encountered an error when changing the information in item number 3 to mathematical notation. Therefore, to strengthen the results of the analysis, an interview was conducted. The following is an interview excerpt with the subject:

R: You were correct in answering question number 3 but only wrong in thinking about the picture. Now I ask, what do you suppose of $\mathrm{x}$ and $3 \mathrm{x}$ ?

S25: hm .. DC and AB ...

$\mathrm{R}$ : Well, that's right, if $\mathrm{x}$ is $\mathrm{DC}$ and $3 \mathrm{x}$ is $\mathrm{AB}$, why in this picture you thought $\mathrm{x}$ is in $\mathrm{C}$ and $\mathrm{D}$ angles? and suppose $3 \mathrm{x}$ is in the corners of $A$ and $B$ ?

S25: Uh yeah ... I thought they are the same

Therefore, based on the results of the analysis of the answers and interview, it can be concluded that the subject 25 has experienced a transformation error due to the subject assumed the sides of the trapezoid to $\mathrm{x}$. However, after it was applied to the $\mathrm{x}$ notation image, it precisely represents an angle.

b. Subjects with Moderate Mathematical Problem-solving ability

The subject with moderate mathematical problem-solving ability did transformation errors when the subject cannot explain the concepts or formulas used and cannot transform them into mathematical sentences. The following are examples of a student's answer with moderate problem-solving ability in item 2:

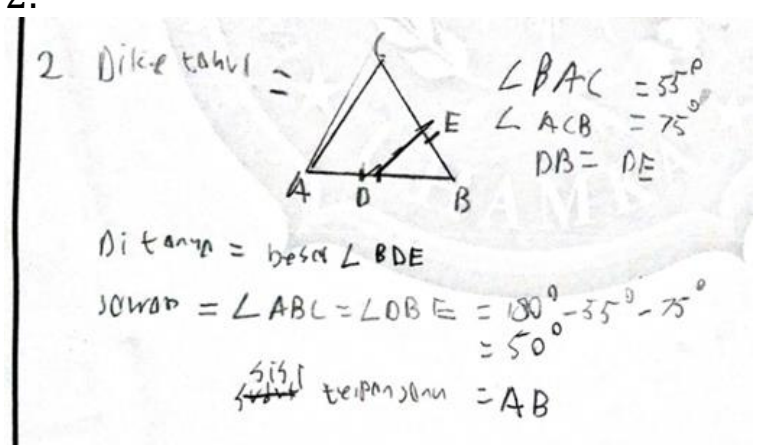

Figure 4. An Answer by a Student with Moderate Mathematical Problem-solving Ability

Based on the answer, subject 17 did not change the information into a mathematical sentence or a picture. Therefore, to strengthen the results of the analysis, an interview was conducted. The following is an excerpt of interviews with the subject:

$\mathrm{R}$ : To solve this problem, what formula or concept did you use?

S17: $\mathrm{Hm}$.. the angle of a triangle, that is 180 degrees.

Therefore, based on the results of the subject's answers and interview, it was known that the subject experienced a transformation error because the subject cannot fully explain the concept or formula used to solve the problem.

c. Subjects with Low Mathematical Problem-solving Ability

The subjects with low mathematical problem-solving ability did transformation errors in using arithmetic 
operations and in determining the formula. The following is a sample answer of a subject with low problem-solving ability in item 2:

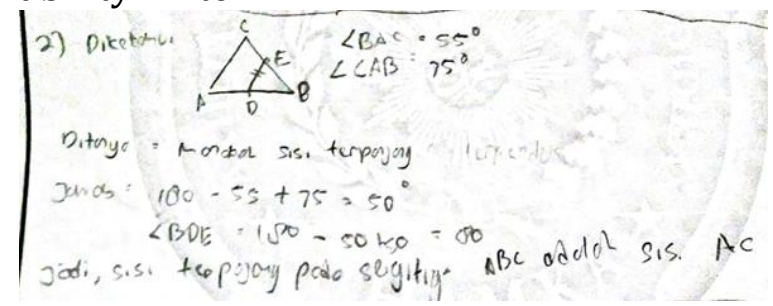

Figure 5. An Answer by a Student with Low Mathematical Problem-solving Ability

The subject was wrong at the completion step. Therefore, to strengthen the results of the analysis, an interview was conducted. The following is an excerpt of an interview with the subject:

R: Okay, now we are going to the completion step. Take a look at this section, why would $180-55+75$ is 50 ? what should it be?

S2: Uh yeah ... that's the wrong sign ... um ... the numbers should all be deducted.

R: So, how should it be written?

S2 $\quad: 180-55-75=50$.

Therefore, based on the results of the analysis of the answer and interview, it can be concluded that the subject experienced a transformation error caused by the error in using the operation sign.

So, it can be concluded that all subjects experienced a transformation error even though the indicators were different. This is supported by the results of the study by (Yusnia \& Fitriyani, 2016) who state that transformation error is when students cannot write or mention formulas or calculations that are relevant to the question request. This happens because students rarely face problemsolving problems.

\section{Process Skill Error}

The subjects are said to make a process skill error when they do not know the completion step, experience an error in the calculation, and could not complete the completion steps. The error made by the subjects in each category of problemsolving ability is as follows:

a. Subjects with High Mathematical Problem-solving Ability

The subject with high mathematical problem-solving ability did a process skill error when performing the calculation process. In Figure 6 below, it appears that the subject was able to plan the completion steps well. However, there was an error in the calculation.

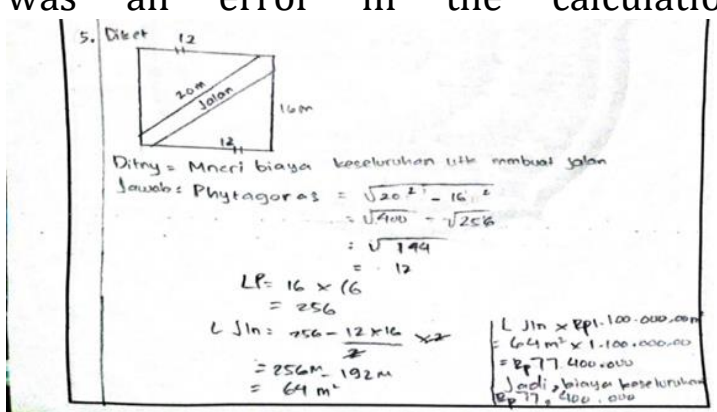

Figure 6. The Answer of Student with

High Mathematical Problem-solving Ability

To find out the factors that caused the error, the following is an excerpt of an interview with the subject:

R: Okay, now try to pay attention to your answer. What is the result of 64 multiplied by $1,100,000$ ?

S25 : 77,400,000

R: Okay, now let's recalculate

S25: Okay ma'am (re-multiplying on paper)

R: Okay, what's the answer?

S25:70,400,000

R: Why did you answer 77.4 million?

S25: I counted it too quickly

Based on the results of the analysis, the subject did not careful enough during the calculation process.

b. Subjects with Moderate Mathematical Problem-solving Ability

The subjects with moderate mathematical problem-solving ability did process skill errors when performing the 
calculation process, unable to determine the steps of completion, and calculation concept errors. The following is a sample answer by a subject with moderate problem-solving ability in item 2 . Based on the answer in Figure 7, it appears that the subject cannot complete the steps of problem-solving in item number 2 in full.

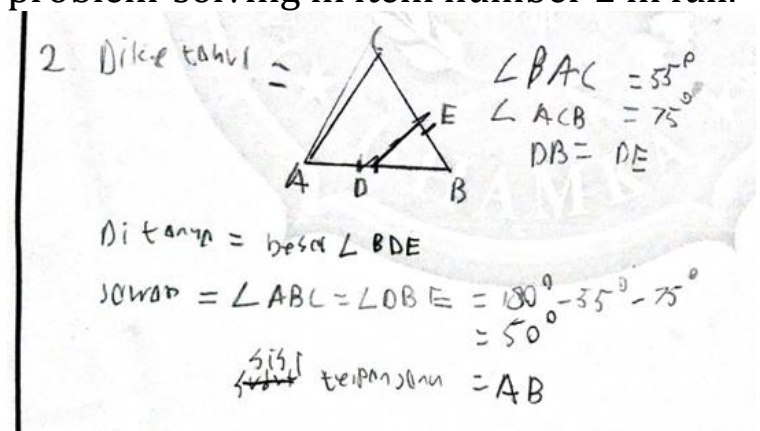

Figure 7. The Answer of Student with Moderate Mathematical Problem-solving Ability

Therefore, to strengthen the results of the analysis, an interview was conducted. The following is an excerpt of the interview with the subject:

R: Okay, that means the angle of the BDE is

50 degrees huh? Are you sure?

S17: Hmm .. not really

R: Why?

S17: The problem is confusing

Based on the results of the interview with the subject, it appears that the subject made an error in the completion step because the subject was confused in planning the solution to the problem. Based on the analysis of answer and interview, it was known that in question number 2, S17 experienced a process skill error.

\section{c. Subjects with Low Mathematical} Problem-solving Ability

The subjects with low mathematical problem-solving ability did process skill errors when performing the calculation process, unable to determine and complete the steps of completion, and calculation concept errors. The following is an example of a student's answer in item 3. Based on the answer in Figure 8, the completion steps were only halfway and not completed. The subject also made a calculation error where $\mathrm{x}$ multiplied by $\mathrm{x}$ should be $\mathrm{x}^{2}$, but the subject only wrote $x$

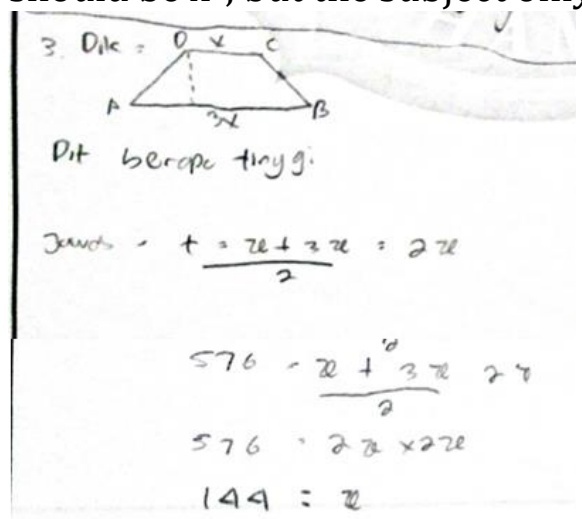

Figure 8. The Answer of Student with Low Mathematical Problem-solving Ability

Therefore, to strengthen the results of the analysis, an interview was conducted. The following is an excerpt of an interview with the subject:

R: Why the calculations stopped at $x=$ 144 ?

S2: Sorry, the time was not enough so it couldn't be finished.

R: That's Okay. Also, is $x=144$ correct?

S2: Hm...should it be squared?

$\mathrm{R}$ : Yes, because $\mathrm{x}$ multiplied by $\mathrm{x}$ is $\mathrm{x}^{2}$. Why did you write $\mathrm{x}=144$ ?

S2: Yes, the squared sign was left behind because the time was over

Therefore, based on the results of the analysis of answer and interview, subject 2 experienced a process skill error. It can be concluded that all subjects experienced the process skill error even though the indicators were different. This was supported by the results of the study by (Mahmudah, 2018) which states the type of process skill errors mostly due to miscalculations or stuck in calculations as well as carelessness in calculations.

\section{Writing Error (Encoding Error).}

The subject is said to make a writing error (encoding error) when the subject is unable to show the final answer and conclusion and does not write the unit in full. The writing errors made by the 
subjects in each category of problemsolving ability are as follows:

a. Subject with High Mathematical Problem-solving Ability

The subject with high mathematical problem-solving ability did writing errors by not writing the unit of calculation and presenting the wrong final answer and conclusion. The following is the sample answer by a subject with high problem-solving ability in item 4 .

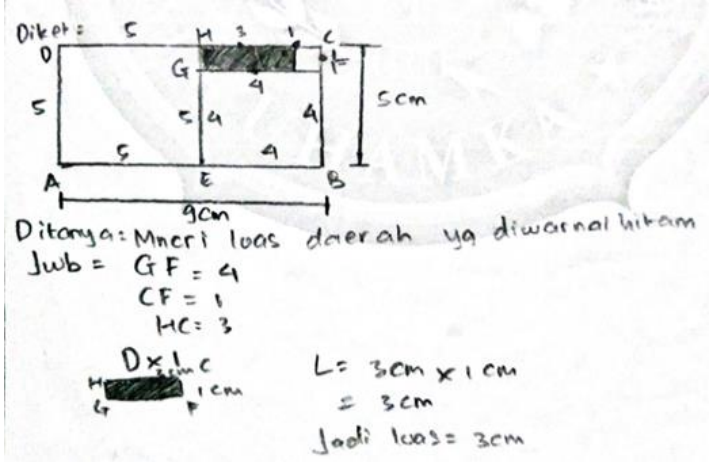

Figure 9. The Answer of Student with High Mathematical Problem-solving Ability

In Figure 9, it can be seen that the final answer and conclusion are not equipped with a unit of calculation. Therefore, to strengthen the results of the analysis, an interview was conducted. The following is an excerpt of an interview with the subject:

R: Okay right. Your answer was correct in the completion step. However, there was a slight error. Try to look at your answer sheet, which unit is used to state that area?

S25: Square centimeter?

$\mathrm{R}$ : Well ... then why did you write $\mathrm{cm}$ ?

25: Oh right, I forgot, I wasn't careful enough because I was too scared to run out of time.

Based on the analysis of the answers and interviews, it can be seen that the subject 25 made a writing error by incorrectly wrote the unit due to the fear of running out of time. b. Subjects with Moderate Mathematical Problem-solving Ability

The subjects with moderate mathematical problem-solving ability did writing errors because the answer was not accompanied by a unit of calculation and the conclusions and final answers produced were wrong. The following is a sample answer of a subject with high problem-solving ability in item 3 .

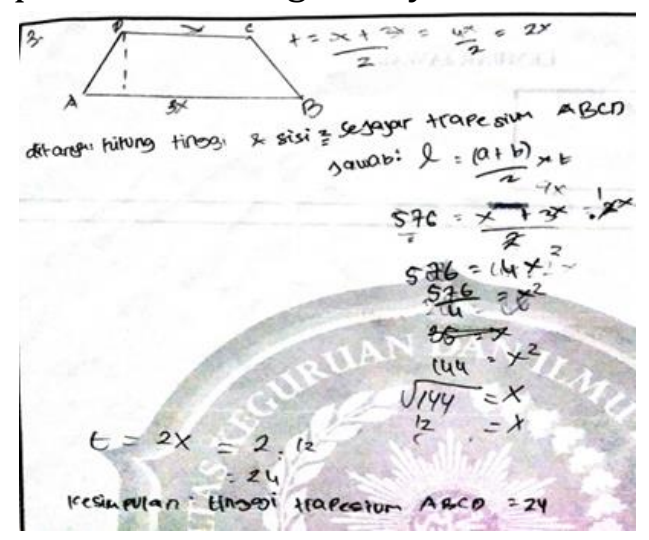

Figure 10. The Answer of Student with Moderate Mathematical Problem-solving Ability

Based on Figure 10, it can be seen that the subject produced the wrong final result conclusion. This happened because, in the previous analysis, the subject was unable to solve the problem at the process skill step so that the subject got the wrong final result. Based on the written answer, the subject made a writing error (encoding error).

c. Subjects with Low Mathematical Problem-solving Ability

The subjects with low mathematical problem-solving ability did writing errors by no writing the unit of calculation and wrong conclusion and final answer. The following is a sample answer by a subject with low problem-solving ability in item 1 . 


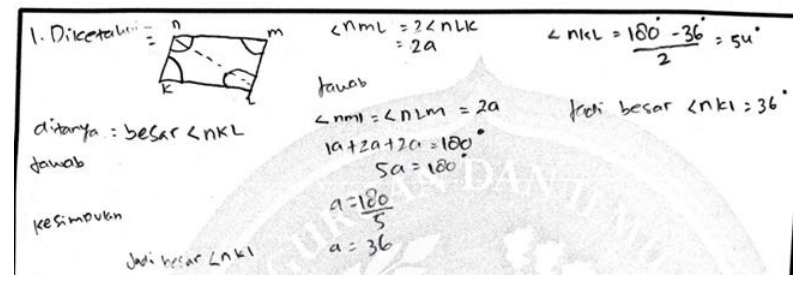

Figure 11. The Answer of Student with Low Mathematical Problem-solving Ability

Based on the answer in Figure 11, the subject did writing errors where the magnitude was not equipped with a unit of calculation and the conclusion written was not the same as the final answer. Therefore, to strengthen the results of the analysis, an interview was conducted. The following is an excerpt of an interview with the subject:

R: Okay, let's continue, let's see your answer, $\mathrm{a}=36$. Well, what did 36 represent?

S23: Angle

R: Well that's right, if it represented the magnitude, what should be the unit?

S23: Hm ... degrees...

R: That's right, then why didn't you write it down?

S23: I forgot, I was not aware of the unit hadn't been written yet.

Based on the analysis, the subject experienced a writing error (encoding errors) because of incorrect answers and not writing the units of degrees.

So, it can be concluded that all subjects experienced writing errors (encoding errors) even though the indicators were different. This is similar to the results of studies by (Mahmudah, 2018) which states that the type of writing error or notation errors mostly caused by students being not careful in the use of units.

Therefore it can be concluded that there were five types of errors made by the research subjects. The results of this study are different from the results of research conducted by (Yusnia \& Fitriyani, 2016) that in the algebraic arithmetic operations material, the subjects experienced only four types of errors, namely: understanding errors, transformation errors, process skill errors, and writing errors.

\section{CONCLUSIONS AND SUGGESTIONS}

Based on the analysis and discussion, the following research conclusions are obtained:

1. Errors - There were five types of errors in mathematical problem-solving ability on triangular and quadrilateral material experienced by students with high, moderate, and low problem-solving ability were. The errors were reading errors, comprehension errors, transformation errors, process skill errors, and writing errors.

2. The factors that caused the errors namely:

(a) Not accustomed to working on nonroutine questions.

(b) Spending less time in solving math problems given.

(c) In a hurry to read and understand the questions.

(d) Lack of accuracy in the calculation process.

Lack of understanding of the basic concepts of calculation such as algebra, calculation, and reduction of fractions.

\section{REFERENCES}

Ahmad, S. (2017). Efektivitas Model Pembelajaran Learning Cycle 5E Berbantuan Alat Peraga Pada Materi Segitiga Kelas VII. Jurnal Ilmiah Pendidikan Matematika, 3(1), 63-74. Aisyah, P. N., Khasanah, S. U. N., Yuliani, A., \& Rohaeti, E. E. (2018). Analisis Kemampuan Pemecahan Masalah Matematis Siswa SMP Pada Materi Segiempat dan Segitiga. JPMI Uurnal Pembelajaran Matematika Inovatif), 1(5), 1025-1036. 
Aisyah, P. N., Nurani, N., Akbar, P., Yuliani, A., Siliwangi, I., Jendral, J. T., \& Cimahi, S. (2018). Analisis Hubungan Kemampuan Pemecahan Masalah Matematis dan Self Confidence Siswa SMP. Journal On Education P, 1(1), 58-65.

Amam, A. (2019). Penilaian Kemampuan Pemecahan Masalah Matematis Siswa Smp. TEOREMA: Teori Dan Riset Matematika, 2(1), 39. https://doi.org/10.25157/teorema.v $2 \mathrm{i} 1.765$

Badan Standar Nasional Pendidikan. (2006). Standar Isi Untuk Satuan Pendidikan Dasar dan Menengah (Vol. 33, pp. 1-505). https://doi.org/10.19744/j.cnki.111235/f.2006.09.027

Fauziah, R., Maya, R., \& Fitrianna, A. Y. (2018). Hubungan Self Confidence Terhadap Kemampuan Pemecahan Masalah Matematis Siswa SMP. Jurnal Pembelajaran Matematika Inovatif, 1(5), 881-886. Retrieved from https://journal.ikipsiliwangi.ac.id/in dex.php/jpmi/article/view/1967/28 2

Fitriatien, S. R. (2019). Analisis Kesalahan Dalam Menyelesaikan Soal Cerita Matematika Berdasarkan Newman. JIPMat, 4(1), 128-134. https://doi.org/10.26877/jipmat.v4i 1.3550

Hadiyanti, Y. R. (2016). Deskripsi Kesalahan Siswa dalam Menyelesaikan Soal - Soal Penerapan Bangun Datar Segi Empat di Kelas VII D Semester 2 SMP YPK Kotaraja. Jurnal Ilmiah Matematika Dan Pembelajarannya, 2(1), 10-17.

Mahmudah, W. (2018). Analisis Kesalahan Siswa dalam Menyelesaikan Soal Matematika Bertipe Hots Berdasar Teori Newman. Jurnal UJMC, 4(1), 4956.

Oktaviana, D. (2018). Analisis Tipe Kesalahan Berdasarkan Teori Newman Dalam Menyelesaikan Soal
Cerita Pada Mata Kuliah Matematika Diskrit. Edu Sains: Jurnal Pendidikan Sains \& Matematika, 5(2), 22. https://doi.org/10.23971/eds.v5i2.7 19

Rianti, R. (2018). Profil Kemampuan Pemecahan Masalah Matematis Siswa SMP Pada Materi Bangun Ruang Sisi Datar. JIPM (Jurnal Ilmiah Pendidikan Matematika), $\quad 6(2), \quad 82$. https://doi.org/10.25273/jipm.v6i2. 2007

Sari, A. R., \& Aripin, U. (2018). Analisis Kesalahan Siswa Dalam Menyelesaikan Soal Cerita Bangun Datar Segiempat Ditinjau Dari Kemampuan Pemecahan Masalah Matematik Untuk Siswa Kelas VII. Jurnal PEmbelajaran Matematika Inovatif (JMPI), 1(6), 1135-1142. Retrieved from https://journal.ikipsiliwangi.ac.id/in dex.php/jpmi/article/view/2187/33 4

Sholihah, S. Z., \& Afriansyah, E. A. (2017). Analisis Kesulitan Siswa Dalam Proses Pemecahan Masalah Geometri Berdasarkan Tahapan Berpikir Van Hiele. Mosharafa, 6(2), 267-272.

Ulvah, S., \& Afriansyah, E. A. (2016). Kemampuan Pemecahan Masalah Matematis Siswa ditinjau melalui Model Pembelajaran SAVI dan Konvensional. Jurnal Riset Pendidikan, 2(2), 142-153. Retrieved from

http://hikmahuniversity.ac.id/lppm /jurnal/2016/text07.pdf

Yusnia, D., \& Fitriyani, H. (2016). Identifikasi Kesalahan Siswa Menggunakan Newman's Error Analysis (NEA) Pada Pemecahan Masalah Operasi Hitung Aljabar. Seminar Nasional Pendidikan, Sains Dan Teknologi, 78-83.

Yuwono, M. R. (2016). Analisis Kesulitan Belajar Siswa Kelas VII SMP Dalam Menyelesaikan Soal Materi Segitiga dan Alternatif Pemecahannya, (95), 
Desimal, 3 (1), 2020 - 136

Rosida Yahya Asriyani, Isnaini Handayani, Windia Hadi

$14-25$. 